\title{
Use of intracellular amino acid analysis as an indicator of the physiological status of natural dinoflagellate populations
}

\author{
Kevin J. Flynn ${ }^{1}$, Kenneth J. Jones ${ }^{2}$, Robin Raine ${ }^{3}$, Jocelyn Richard ${ }^{2}$, Krystyna Flynn $^{1}$ \\ ${ }^{1}$ Algal Research Unit, Biological Sciences, University of Wales, Swansea, Singleton Park, Swansea SA2 8PP, United Kingdom \\ ${ }^{2}$ Dunstaffnage Marine Laboratory, PO Box 3, Oban, Argyll PA34 4AD, United Kingdom \\ ${ }^{3}$ Department of Microbiology, University College Galway, Galway, Ireland
}

\begin{abstract}
The physiological status of 2 dinoflagellate populations in Bantry Bay, Ireland, was examined by use of amino acid analysis. Observations were made during two 24 h periods. In one, during an

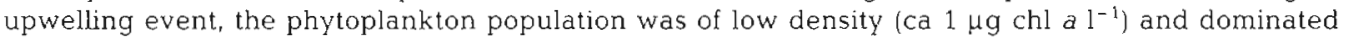
mainly by Ceratium, Prorocentrum and Scrippsiella species. In the second (1 wk later), following relaxation of the upwelling and an incursion of surface water from the adjacent open coastal region, the phytoplankton community was dominated by Ceratium spp. and Gyrodinium aureolum with chl a concentrations up to 10 times higher. During the first sampling period, there was evidence of slight $\mathrm{N}$-stress at the surface; the ratio of intracellular glutamine/glutamate $(\mathrm{Gln} / \mathrm{Glu})$ was 0.35 , increasing with ammonium spiking. There was evidence of C-stress at the chl maximum, where Gln/Glu was high (1.2) and decreased on exposure to increased irradiance. During the second sampling period, Gln/Glu was low (0.1) suggesting a poor $\mathrm{N}$-status. However, there was little or even a negative response of Gln/Glu to ammonium spiking; glutamate responded to the spiking rather than glutamine. The general composition of the intracellular amino acid pool was similar to that at the first period, with high proportions of $\mathrm{N}$-rich amino acids such as arginine. This second population appeared to be physiologically damaged in some way; this would not appear to have been simply a result of $\mathrm{N}$-stress, but perhaps reflected the consequences of the associated advective process and exposure of the algae to high photon flux densities. The concentration of dissolved free amino acids (DFAA) during the second period was up to 4 times higher than at the first, but still dominated by serine and glycine. DFAA appeared to relate more to the presence of zooplankton than to the phytoplankton.
\end{abstract}

KEY WORDS: Dinoflagellate DFAA Intracellular amino acids $\cdot$ Gln/Glu $\cdot$ Nitrogen physiology $\cdot$ Gyrodinium aureolum . Ceratium spp. - Prorocentrum spp. Scrippsiella spp.

\section{INTRODUCTION}

Knowledge of the physiological ecology of dinoflagellate populations is important for the understanding of processes leading to, or promoting, blooms of these algae. Essentially, such blooms may either develop as a result of active algal growth in one location, or by the aggregation of individuals from over a wide area as a consequence of physical processes (Le Févre 1986). More recently, it has been suggested that dinoflagellate blooms may be supported by in situ regeneration of ammonium from the degradation of algal biomass from previous growths, through the activities of graz- ers and the microbial loop in stratified water (Prego 1992, Le Corre et al. 1993). Given the appearance of dinoflagellate populations, one may then question if that population is essentially senescent or if further growth is possible in response to nutrient input from other sources such as rivers or aquaculture (Anderson et al. 1990, Delmas et al. 1992, Fraga et al. 1992, Jiménez et al. 1992).

The aims of this work were to examine the $\mathrm{N}$-status (i.e. degree of $\mathrm{N}$-stress) of dinoflagellate populations off the southwest coast of Ireland. The principal method employed centred on the examination of the intracellular amino acid pool (InAA) of the algae 
Amino acid synthesis is the point at which the processes of $\mathrm{CO}_{2}$-fixation and $\mathrm{N}$-source assimilation meet. As such, the contents of InAA reflect the balance of these 2 processes and of subsequent processes requiring amino acids, such as protein synthesis. Of particular importance, because of its role in the assimilation of intracellular ammonium (from the uptake of ammonium, nitrate, nitrite, urea, or from deamination), is the synthesis of glutamate and glutamine through the activities of the enzymes glutamine synthetase and glutamine-oxoglutarate aminotransferase (collectively termed GS-GOGAT; see Syrett 1981). The use of the ratio of intracellular free glutamine/glutamate (Gln/Glu) as an index for the N-status of algae has been reviewed by Flynn (1990a, 1991). In essence, a low value of Gln/Glu (less than 0.1) during phototrophic growth indicates significant N-stress, while values approaching and exceeding 0.5 indicate decreasing $\mathrm{N}$-stress and an increasing degree of C-stress at the point of intracellular ammonium incorporation. The application of Gln/Glu analysis to studies of dinoflagellates in laboratory culture has been demonstrated by Flynn et al. (1993).

In addition to the determination of Gln/Glu, the response of the algae to a short (20 min or so) dark incubation in the presence of $10 \mu \mathrm{M}$ ammonium was examined. $\mathrm{N}$-stressed cells should use the ammonium, resulting in a rapid increase in the Gln/Glu ratio (Flynn et al. 1989), while there should be little response in $\mathrm{N}$-sufficient cells.

\section{MATERIAL AND METHODS}

The general hydrographic features of Bantry Bay, SW Ireland, distribution of chlorophyll a (chl a), in situ chlorophyll (chl) fluorescence, and dissolved nutrients, were determined during twice-weekly survey cruises along an axial transect of stations in the bay from its head, west of Whiddy Island, to a seaward station, $28 \mathrm{~km}$ west of Mizen Head. The position of the anchor station (Location $3 \mathrm{a}_{;} 51^{\circ} 39^{\prime} \mathrm{N}, 09^{\circ} 40^{\prime} \mathrm{W}$ ), at which the 24 h measurements reported here were made, is indicated in Fig. 1. Other details of these surveys are given in Raine et al. (1993a, b). Phytoplankton species counts were also carried out on water samples collected from the surface and from the chl maximum at each station.

In addition to the survey measurements, a buoyed instrument array was deployed continuously at Location 3a throughout the study period. The buoy was fitted with wind speed and direction sensors (Aanderaa), 2 -pi quantum irradiance sensor (Licor 190s, similar to that used during surveys to measure sub-surface photon flux densities, PFD), and a submersible fluorometer (SeaTech) suspended at a depth of $7 \mathrm{~m}$ below the buoy.
Measurements from these sensors were logged at 20 min intervals using an Aanderaa 12-channel data logger, and the data stored in solid state memory. Alongside the buoy (within $50 \mathrm{~m}$ ), 2 further moorings were deployed, one consisting of 4 Aanderaa current meters held at 5, 10,20, and $30 \mathrm{~m}$ from the seabed, and a thermistor chain of 11 sensors spaced at approximately $3 \mathrm{~m}$ intervals between 2 and $31 \mathrm{~m}$ from the seabed. Data from these instruments were logged at 20 min intervals, synchronized with those of the main buoy. It was at the site of this buoy that the work reported here was performed.

Water samples were taken over two 24 h periods, on 29 July 1991 (hereafter 'Stn I'), and on 5 August 1991 ('Stn II') whilst the ship was at anchor. Samples were taken at approximately the middle of the dark ('night'; $00: 00 \mathrm{~h}$ or $01: 00 \mathrm{~h}$ GMT) and light ('day'; 13:00 h or 14:00 h GMT) periods at depths to cover the surface mixed layer, pycnocline, chl maximum and bottom mixed layer, and at the chl maximum at various other times, using 5 l Van Dorn sampling bottles.
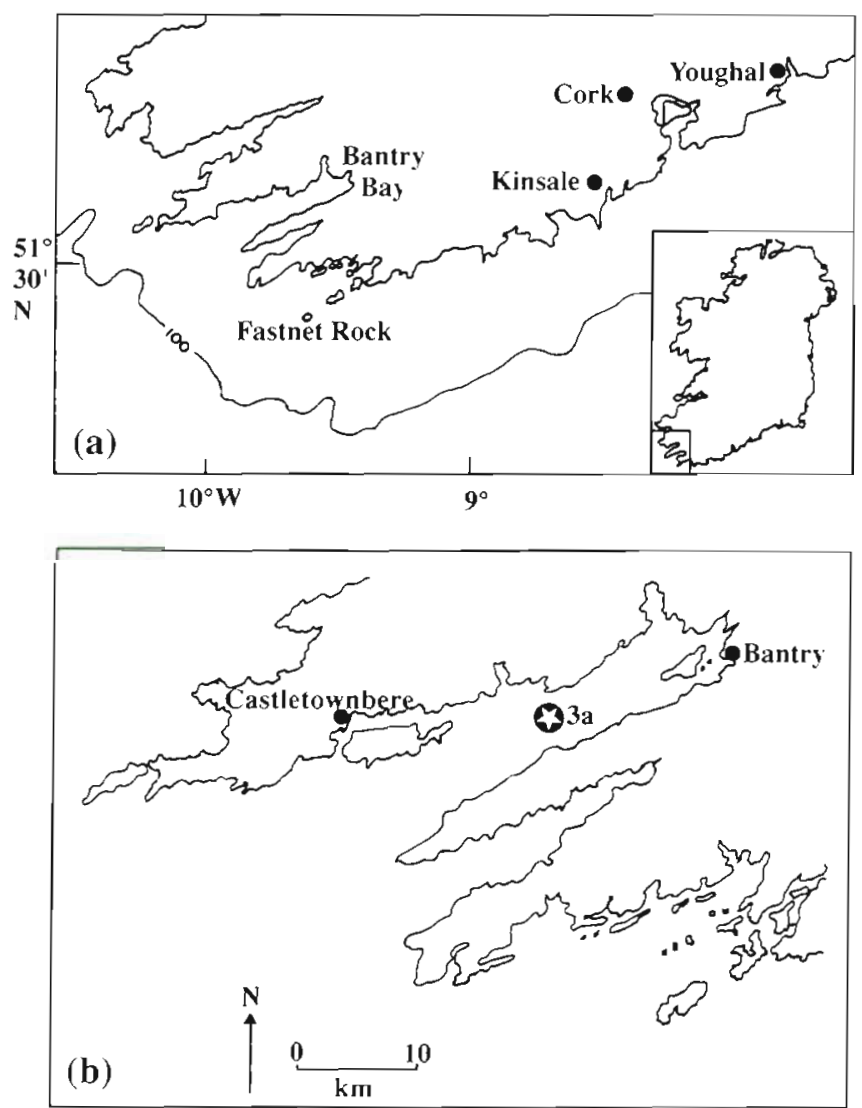

Fig. 1. Map showing (a) location of Bantry Bay in SW Ireland (100 $\mathrm{m}$ depth contour indicated), and (b) position of study site and buoyed instrument array at Location 3 a half way between the towns of Bantry and Castletownbere 
Samples for amino acid analysis were handled as rapidly as possible after collection; volumes of 11 were taken immediately from the sampling bottle into a polypropylene jug. To a $200 \mathrm{ml}$ volume of seawater in a $250 \mathrm{ml}$ tissue culture vessel (Cel-Cult, Sterilin), $\mathrm{NH}_{4} \mathrm{Cl}$ was added to give a final concentration of $10 \mu \mathrm{M}$, and the sample incubated in darkness. These spiked volumes were sampled at $15 \mathrm{~min}$ (filtration completed by 20 min after addition of the $\mathrm{NH}_{4} \mathrm{Cl}$ ) and, for Stn II, also at $35 \mathrm{~min}$ (filtration completed by $40 \mathrm{~min})$. Between these times, samples were taken from the jug as controls (no nutrient addition); the first control had normally been handled by $10 \mathrm{~min}$ and the second (Stn I only) by 40 min after recovery of the sample bottle. Samples $(50$ or $100 \mathrm{ml}$ ) were filtered onto pre-ashed GF/C filters ( $25 \mathrm{~mm}$, Whatman) held in a filter holder made from a Millipore Swinnex unit (rubber seal discarded), which had the female end cut off close to the screw-thread, and a funnel made from a clear polystyrene tube epoxied to it. The first $5 \mathrm{ml}$ or so of filtrate was allowed to run to waste under gravity, the next 5 to $10 \mathrm{ml}$ was used to rinse and then fill, again under gravity, two $1.5 \mathrm{ml}$ microtubes (Eppendorf pattern) with filtrate for analysis of dissolved free amino acids (DFAA). The remaining volume was filtered under low vacuum $150 \mathrm{~mm}$ Hg applied via a tube attached to the male end of the filter unit), and the filter then dried at full vacuum for a few seconds, placed in a microtube, and frozen together with the samples for DFAA. On one occasion a copepod was trapped and was removed from the filter with forceps before freezing. During these procedures, care was exercised not to contaminate the samples; gloves were worn at all times and the forceps, filters, filter holder and microtubes were kept separate from those used for other analyses. Samples were maintained frozen $\left(-20^{\circ} \mathrm{C}\right)$ prior to analysis. Extracts for InAA were made into $1 \mathrm{ml}$ HPLC grade water at $70^{\circ} \mathrm{C}$, and HPLC analysis for DFAA and InAA performed as detailed by Flynn (1988) and Flynn \& Flynn (1992). Ammonium was also assayed during the analysis of DFAA.

Particulate carbon and nitrogen were determined following filtration of $0.5 \mathrm{I}$ samples through pre-ashed GF/C (Stn I) or GF/F (Stn II) filters, using a LECO 900 $\mathrm{CHN}$ analyser, with alanine as the standard with filterblanks.

Nitrate was analysed according to Strickland \& Parsons (1972), after filtration of samples through GF/C filters. Chl a was determined in samples collected on $\mathrm{GF} / \mathrm{F}$ filters, and frozen at $-20^{\circ} \mathrm{C}$ in $15 \mathrm{ml}$ polypropylene centrifuge tubes. Pigments were extracted overnight with $90 \%$ neutralized acetone (Tett \& Wallis 1978), and chl a determined with a Turner Designs model 10 fluorometer using the filter configuration of Jones et al. (1984).

\section{RESULTS}

\section{Hydrography}

Density stratification was controlled by temperature throughout the study period. From 14 to 30 July, cool shelf water intruded into Bantry Bay at depth and uplifted the pycnocline from $35 \mathrm{~m}$ to $7 \mathrm{~m}$ and intensified the gradient within it (Fig. 2; see Raine et

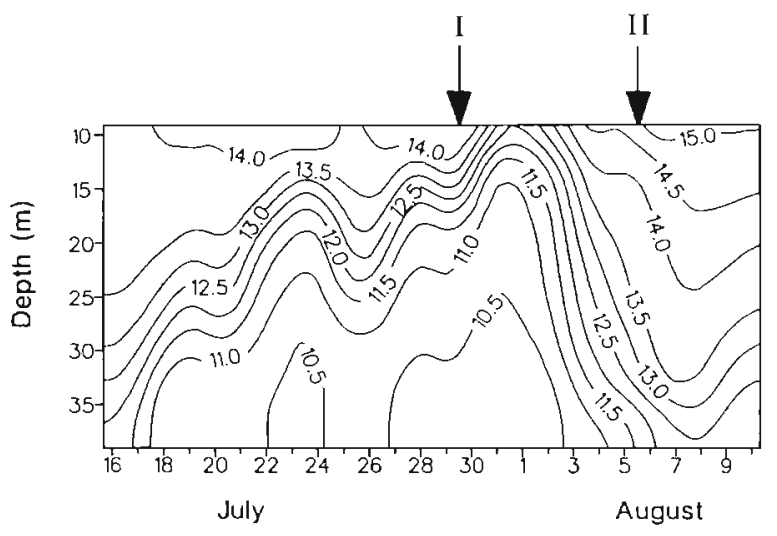

Fig. 2. Continuous time series of vertical temperature values between 16 July and 10 August 1991 at Location 3a in Bantry Bay (see Fig. 1). Data were obtained from a thermistor chain attached to an instrument buoy. Arrows indicate the dates of the 24 h sampling Stns I \& II

al. 1993a, b). The first experiment (Stn I) was conducted during the latter stages of this occurrence (Fig. 3a, b). After 30 July, a net outflow of bottom water was compensated for by an inflow at the surface of warm shelf surface water (Fig. 2) with a rapid increase in the depth of the pycnocline (Fig. 3c, d). In consequence the vertical column structure during each experimental period was markedly different. At Stn I, a sharp $\left(4^{\circ} \mathrm{C}\right)$ thermocline existed at 8 to $10 \mathrm{~m}$ and showed only slight variability over the $24 \mathrm{~h}$ sampling period. At Stn II, water column stratification was more complex, with weak thermoclines (gradients of $<2^{\circ} \mathrm{C}$ ) at 5 and $20 \mathrm{~m}$ for much of the $24 \mathrm{~h}$ period. A third, stronger thermocline existed at $35 \mathrm{~m}$ at the interface of the bay water and the cool shelf water from the earlier intrusion. Small changes in the density layering of the water during both experiments were probably insignificant in causing changes to community structure or physiology during each $24 \mathrm{~h}$ experimental period. The average maximum PFD at the water surface during the week previous to Stn I (21 to 28 July) was only $250 \mu \mathrm{mol} \mathrm{m} \mathrm{m}^{-2}$ $\mathrm{s}^{-1}$, while before Stn II (29 July to 5 August) it was over $1250 \mu \mathrm{mol} \mathrm{m} \mathrm{m}^{-2} \mathrm{~s}^{-1}$. 

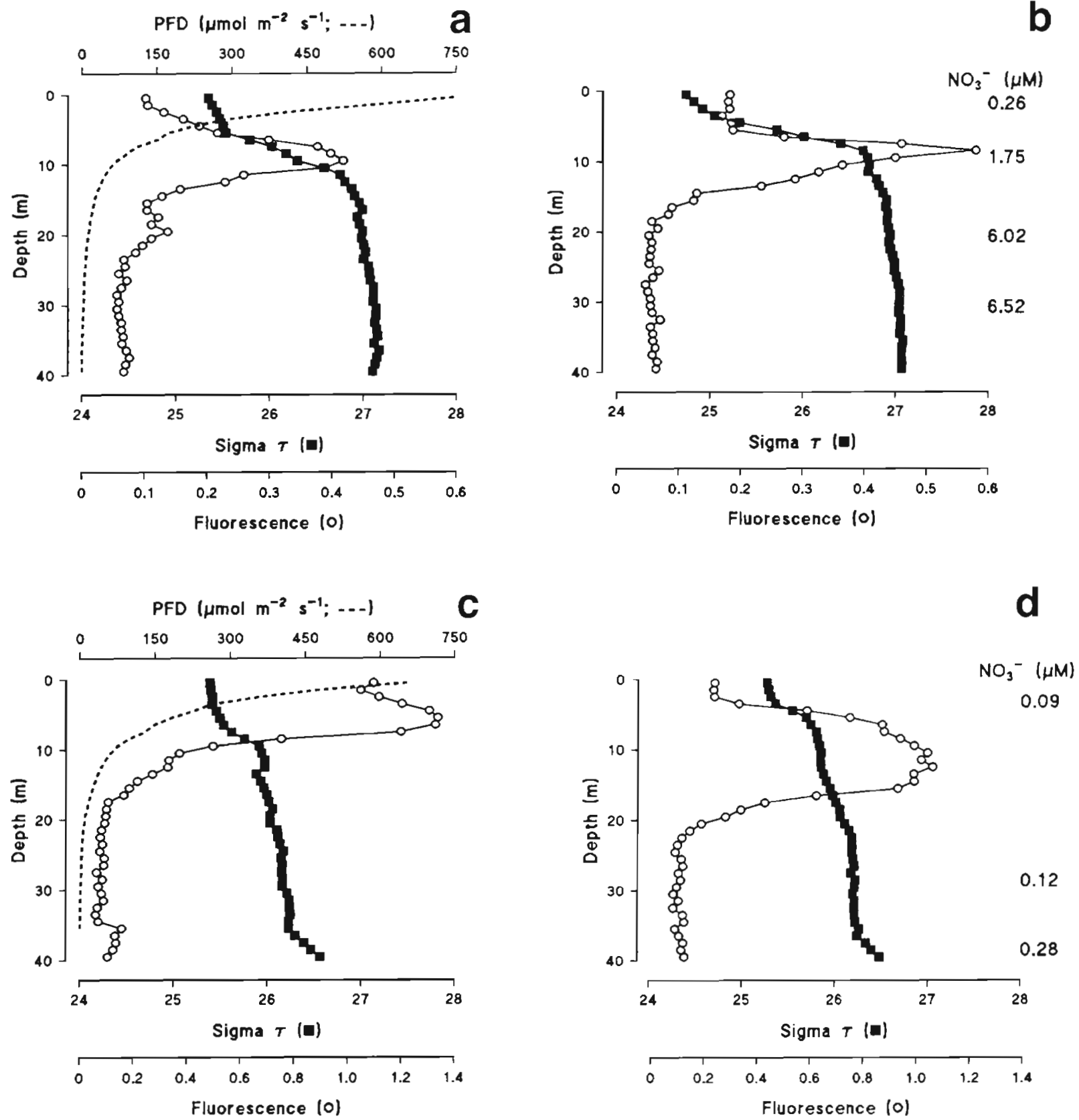

Fig. 3. Data for water density (sigma $\tau$ ), in vivo chl fluorescence (volts), photon flux density (PFD), and nitrate for Stn 1 (a) day of 29 July 1991; (b) night] and Stn II [(c) day of 6 August $_{i}$ (d) night of 5 August 1991]. At Stn I, the pycnocline had been raised following an intrusion of cool shelf water at depth (see Fig. 2). By the time of Stn II, a net outflow of the bottom water was compensated for by an inflow at the surface of warm shelf surface water (Fig. 2) with a rapid increase in the depth of the pycnocline

\section{Nutrients and chlorophyll}

Concentrations of nitrate (Fig. 3b, d) indicate nitrate depletion at the surface at Stn I, and throughout the water column at Stn II. Concentrations of phosphate ranged from 0.3 to $0.9 \mu \mathrm{M}$ at Stn $\mathrm{I}$, and one-third of those values at Stn II. Concentrations of ammonium (determined by HPLC during measurement of DFAA) were always below $0.1 \mu \mathrm{M}$. At Stn $\mathrm{I}$, the in vivo chl fluorescence maximum was at 8 to $10 \mathrm{~m}$ (values at the surface of ca $30 \%$ of maximum, with little diurnal shift; Fig. 3a, b), while at Stn II the maximum was at $5 \mathrm{~m}$ in the daylight with a broad peak at $10 \mathrm{~m}$ at night (Fig. $3 c, d$ ). These contrasts are likely to relate to the 


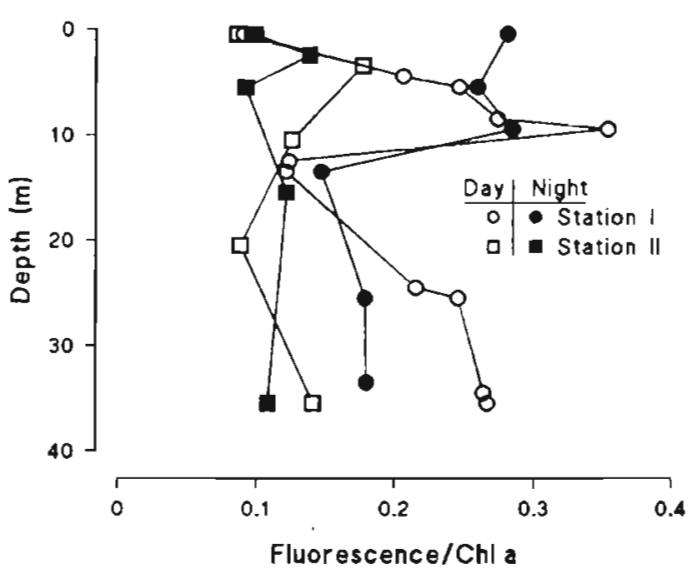

Fig. 4. Ratios of in vivo chl fluorescence (as in Fig. 3) to extracted chl $a\left(\mu \mathrm{g}^{-1}\right)$ during day and night at Stns I \& II

distinct differences in the position and intensity of the upper thermocline between the 2 study dates. There was also a difference between the ratio of in vivo chl fluorescence to extracted chl a between the 2 dates (Fig. 4). The pattern of this ratio at Stn I during day and night is consistent with the algae being subjected to low PFD at $10 \mathrm{~m}\left(25 \mu \mathrm{mol} \mathrm{m}^{-2} \mathrm{~s}^{-1}\right)$ during the day. The fluorescence response at Stn II was markedly lower than that at Stn I, with little diurnal shift.

\section{Phytoplankton populations and $\mathrm{C} / \mathrm{N}$ ratios}

The algal population at Stn I was dominated by Ceratium spp. (40\% biomass, as estimated by biovolume, at $10 \mathrm{~m})$, Prorocentrum micans (25\%), Scrippsiella spp. $(17 \%$, including some as cysts), and Dinophysis spp. $(15 \%)$. At Stn II, the population was dominated by Ceratium spp. $(40 \%$ at $9 \mathrm{~m}$ ) and Gyrodinium aureolum $\left(50 \%\right.$, reaching 150000 cells $\left.1^{-1}\right)$. The cell numbers and biomass (as biovolume) at Stn II were 7 and 8.7 times those at Stn I; at the daytime chl maximum, total cell numbers were $30000 \mathrm{l}^{-1}$ and $212000 \mathrm{l}^{-1}$, with biovolumes of $440 \times 10^{6} \mu \mathrm{m}^{3} \mathrm{l}^{-1}$ and $3900 \times 10^{6} \mu \mathrm{m}^{3} \mathrm{l}^{-1}$ at Stns I \& II respectively. At both stations, the contributions by other algae (diatoms and cryptophytes) were insignificant. The $\mathrm{C} / \mathrm{N}$ ratios for the 2 populations were ca 7.25 and 8 respectively.

\section{Zooplankton}

Vertical tows were taken over the entire water column during the day and night at each station. Numbers of Temora longicornis and Acartia clausi were similar at both stations ( 40 to $50 \mathrm{~m}^{-3}$ of each), while numbers of Pseudocalanus elongatus, Centropages hamatus, copepod nauplii, and early copepodites were lower at Stn II. Concurrently, there were increases in the numbers of Calanus copepodites, Centropages typicus, and 6-fold increases in the numbers of the cladoceran Evadne nordmanni and of appendicularians (reaching 630 and $280 \mathrm{~m}^{-3}$ respectively) at Stn II. The total number of zooplankters of all types were $760 \mathrm{~m}^{-3}$ and $1910 \mathrm{~m}^{-3}$ at Stns I and II respectively.

\section{Intracellular amino acids}

Data for the changes in glutamate and glutamine during ammonium spiking of samples taken from the chl fluorescence maximum (Fig. 3) suggest significant differences in the physiology of the populations. At Stn I, both glutamate and glutamine changed in response to the addition of ammonium (Fig. 5a), while at Stn II the response of glutamine was small, and in some
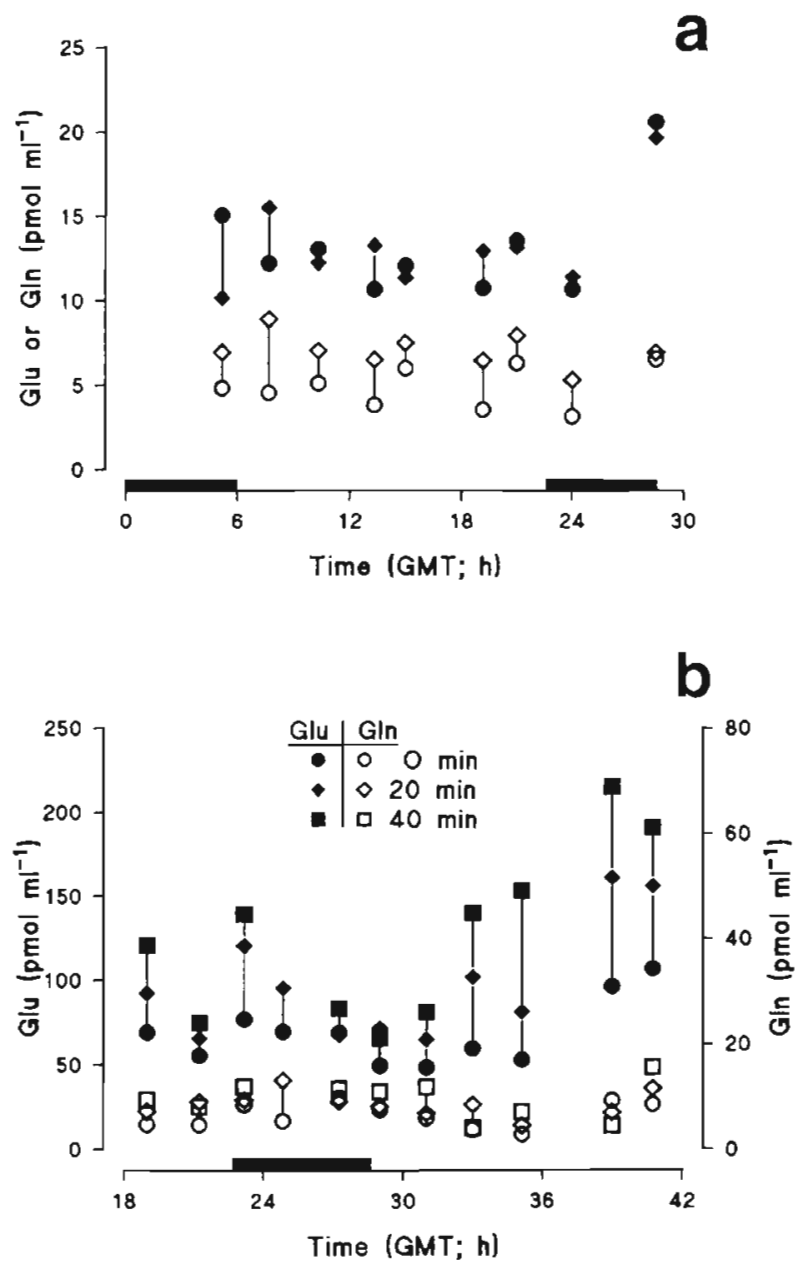

Fig. 5. Changes in intracellular glutamate (Glu) and glutamine (Gln) in response to dark incubations with $10 \mu \mathrm{M} \mathrm{NH} \mathrm{N}_{4} \mathrm{Cl}$ in samples taken (a) at $5 \mathrm{~m}$ during the $24 \mathrm{~h}$ sampling period at Stn I and (b) at the chl fluorescence maximum at Stn II. At Stn II, samples were also taken after $40 \mathrm{~min}$ incubation as well as at $20 \mathrm{~min}$ and, with no addition of $\mathrm{NH}_{4} \mathrm{Cl}$, at 0 min 

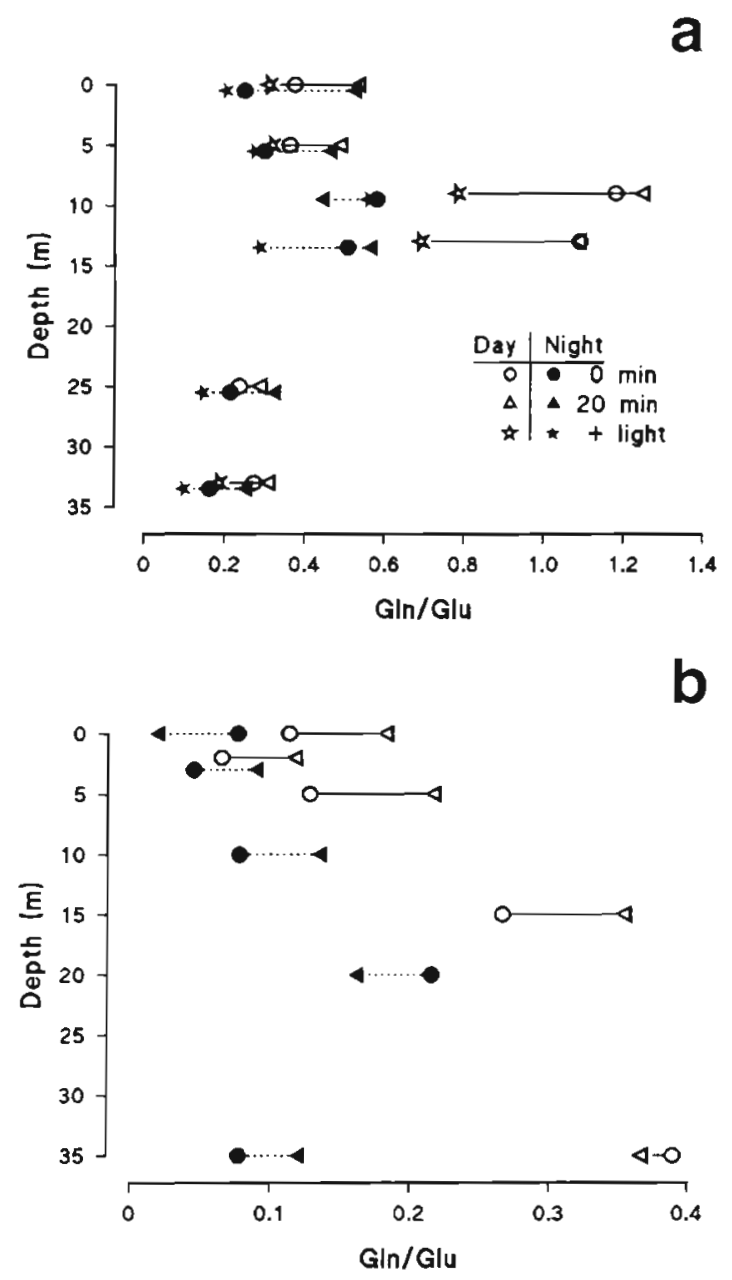

Fig. 6. Changes in the ratio of intracellular glutamine to glutamate $(\mathrm{Gln} / \mathrm{Glu}$ ) in response to $20 \mathrm{~min}$ dark incubations with $10 \mu \mathrm{M} \mathrm{NH}_{4} \mathrm{Cl}$ for samples taken at various depths during the day and night at (a) Stn I, and (b) Stn II. $\star$. no addition of $\mathrm{NH}_{4} \mathrm{Cl}$, but after 30 to 40 min exposure to dim light in ship laboratory (say $75 \mu \mathrm{mol} \mathrm{m}^{-2} \mathrm{~s}^{-1}$; see text)

instances negative (Fig. 5b). Concentrations of glutamate from Stn II were 10 times those from Stn I, in line with the differences in extracted chl a.

Differences between the populations were diso clear from a consideration of the changes in Gln/Glu on addition of ammonium to samples taken from different depths during day or night. At Stn I, Gln/Glu increased with depth to the chl maximum where it reached 1.18 (Fig. 6a). Spiking of samples from surface waters increased Gln/Glu to 0.52 from 0.35 . However, unintentional exposure of the second controls to dim light (not measured, but say, $75 \mu \mathrm{mol} \mathrm{m} \mathrm{m}^{-2}$ $\mathrm{s}^{-1}$ ) in the ship's laboratory led to a significant decrease in Gln/Glu for the samples from 9 and $13 \mathrm{~m}$ (Fig 6a). (The significance of changes in response to PFD over such a short period of time was not recog- nized at the time of sampling.) Gln/Glu values from the upper water column during the night at Stn I (Fig. 6a) were lower than for the day, but were still above 0.3. In contrast with the values at Stn I, samples from the chl fluorescence maximum at Stn II had lower GIn/Glu values $(<0.15$; Fig. 6 b), with a slight increase in the ratio with depth. There were small increases in Gln/Glu on ammonium spiking of the daylight samples at Stn II (Fig. 6b), but in the night there was little response and in some instances the ratio actually fell (Fig. $6 \mathrm{~b}$ at 0 and $20 \mathrm{~m}$ ).

Changes of selected, quantitatively important, InAA with depth are shown in Fig. 7. The concentration of InAA covaried with that of in vivo chl fluorescence, except that there was proportionately more InAA at depth. This could have been due to the presence of poorly fluorescent algae at depth and/or to particulate material containing dinoflagellates (plus, perhaps, heterotrophic dinoflagellates). The presence of the non-protein amine $X$ covaried with other amino acids for Stn I, but was lower in concentration relative to glutamate at Stn II. Levels of glycine fluctuated more with depth and light (day and night) than the other major components of InAA.

When the data were normalized to glutamate (Fig. 8), the following trends became apparent:

(1) During darkness at the chl fluorescence maximum, glycine became qualitatively more dominant (Figs. $7 \mathrm{~b}, \mathrm{~d} \& 8 \mathrm{~b}, \mathrm{c}$ ).

(2) Arginine was most important in samples from the chl fluorescence maximum (Fig. 8a, b; arginine values at $2 \mathrm{~m}$ at Stn II were $75 \%$ of those at the chl maximum as shown in Fig. 8c).

(3) At Stn II, ornithine, lysine, valine and taurine were more dominant relative to glutamate than at Stn $I_{i}$ arginine was also more dominant, especially at night at Stn II (Fig. 8b, c).

A plot of intracellular taurine with chl a (Fig. 9) suggests a relationship between the parameters $(r=0.84)$. The significance of the clusters of points off the perceived correlation is not clear; they are not data from sequential samples or from a particular depth. Nonetheless, this relationship, plus the general appearance of the frequency polygons generated from normalization against glutamate (Fig. 8), give no reason to think that the InAA data were not primarily from an algal source.

\section{Extracellular dissolved free amino acids}

Distributions of DFAA with depth and time for each station are shown in Fig. 10. Concentrations of DFAA at Stn I were generally low with little difference between day (Fig. 10a) and night (Fig. 10b), except for 

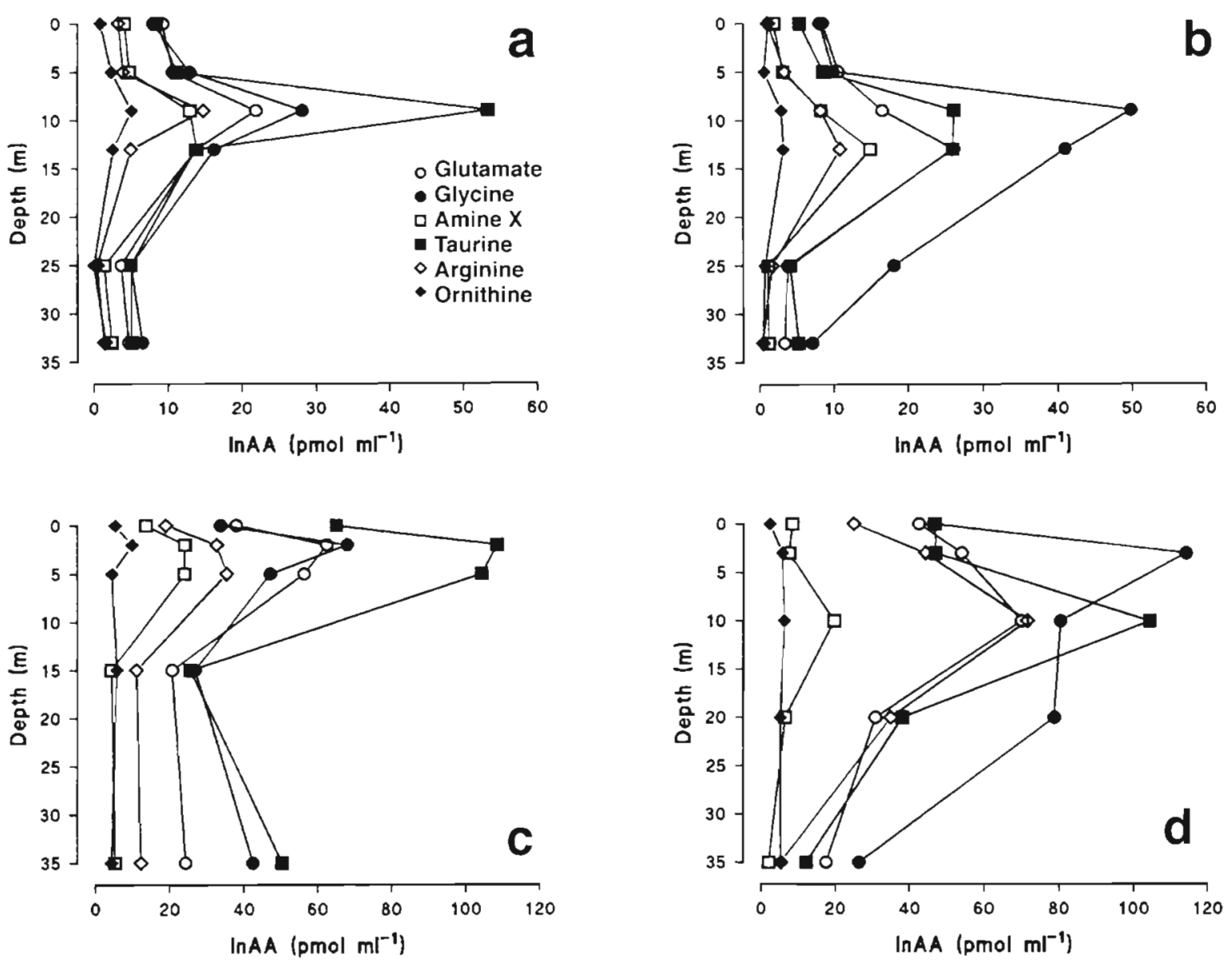

Fig. 7. Concentrations of selected components of intracellular free amino acids (lnAA) for the depth profiles at Stn I (a) in daylight and (b) at night; and at Stn II in (c) daylight and (d) at night. Concentrations are given for amino acids extracted from filtered material per $\mathrm{ml}$ of seawater suspension

a peak of glycine during darkness at $9 \mathrm{~m}$. Glycine was a major component of InAA at this time (Fig. 7b) but levels of taurine (also high in InAA) were undetectable in the DFAA. Concentrations of some components of DFAA, notably glycine, serine and lysine, were higher at Stn II than Stn I, but ornithine was present at Stn I (Fig. 10a, b) while it was very low at Stn II (not shown). In contrast, lysine was detected at Stn II (Fig. 10c, d) but was insignificant at Stn I (not shown). There was no clear link between DFAA and algal biomass; concentrations of DFAA in the upper $15 \mathrm{~m}$ were little different at Stn II compared to Stn I, while there were 6- to 8fold differences in total InAA and (extracted) chl a between the stations.

\section{DISCUSSION}

Of the dominant algae present at these stations, 2 (Prorocentrum micans and Scrippsiella sp.) have been studied by us in laboratory cultures (Flynn et al. 1993). Neither of the dominant dinoflagellates at Stn II (Ceratium sp. and Gyrodinium aureolum) have been studied by us. Unfortunately, MartinJézéquel et al. (1988) give values for InAA in $G$. aureolum which we suspect to be incorrect due to inadequate separation of the amino acids (Flynn \& Flynn 1992). However, the composition of InAA of the algae at Stn II was similar to that observed with other dinoflagellates. Various non-protein amino acids were detected in the InAA, most notably the unidentified amine $X$ and taurine, a combination which appears unique to dinoflagellates (see Flynn \& Flynn 1992). As noted in laboratory experiments with dinoflagellates, the concentrations of amine $\mathrm{X}$ covaried with glutamate, and were lower (relative to glutamate) in darkness and in N-stressed populations (Figs. $7 \& 8$ ). The diurnal changes in Gln/Glu were similar to those observed with laboratory cultures (Flynn et al. 1993). 

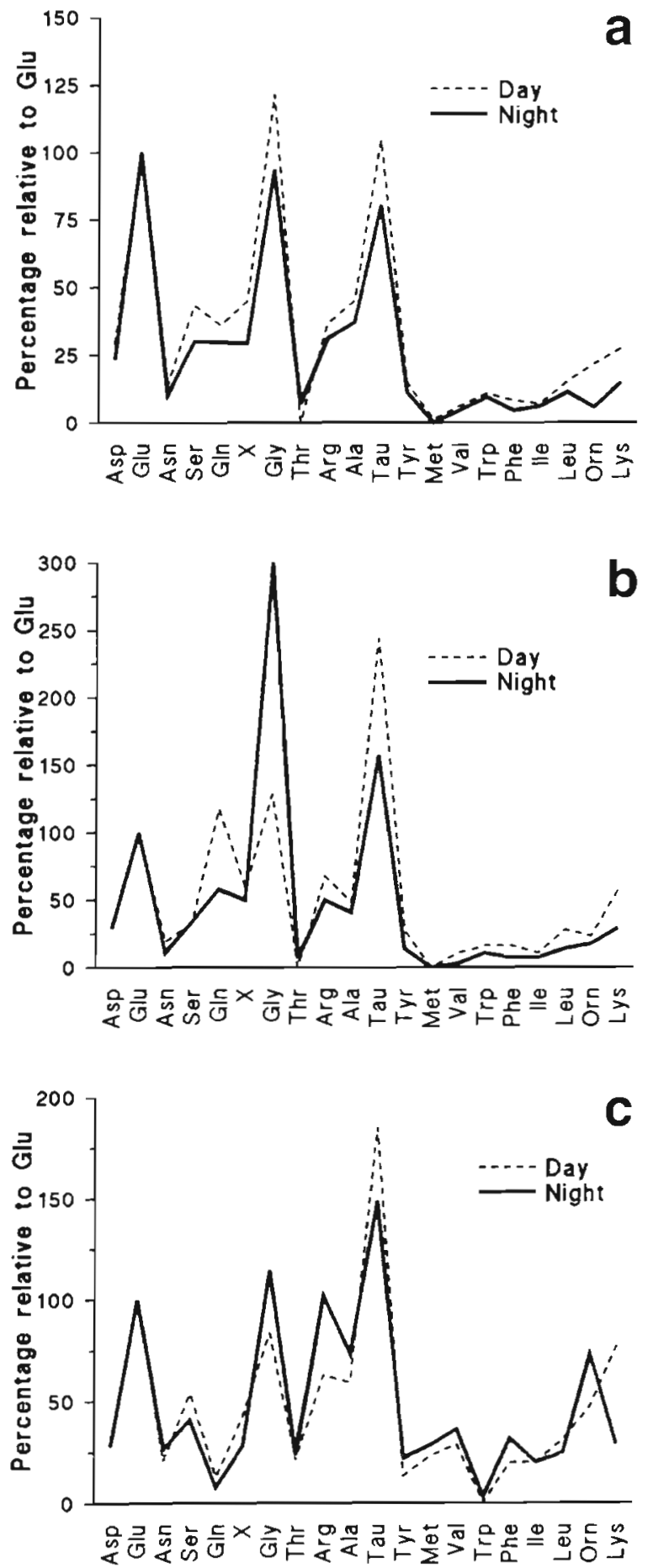

Fig. 8. Frequency polygons of the mole composition of intracellular free amino acids (InAA) relative to glutamate (Glu) from Stn I at (a) $5 \mathrm{~m}$ and (b) $9 \mathrm{~m}$ (the chl fluorescence maximum), and (c) at the chl fluorescence maximum at Stn II. For comparison on a $\mathrm{N}$-basis, values should be multiplied by the number of $\mathrm{N}$ atoms per molecule $e_{i}$ e.g. arginine- $\mathrm{N}$ in (c) would be $400 \%$ of glutamate-N. Quantification of the non-protein amine $X$ assumes a response factor during analysis equal to that for glutamate (see Flynn \& Flynn 1992)

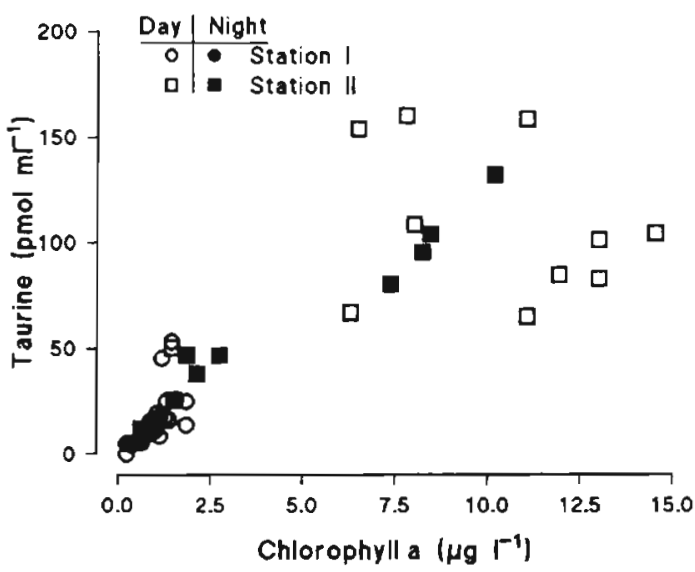

Fig. 9. Plot of intracellular taurine with extracted chl a for all data collected from both Stns I \& II. 'Night' refers to sampling times between sunset and sunrise rather than to a specific time as elsewhere

Stn I was in a water column characterised by low dinoflagellate densities and by predators of various kinds. Nitrate was present at below $0.5 \mu \mathrm{M}$ at the surface, where the daylight Gln/Glu (0.35) suggested slight $N$-stress. At the chl fluorescence maximum, nitrate was at $1.75 \mu \mathrm{M}$ and Gin/Glu was high (>1; Fig. 6a), decreasing on exposure to dim light (not measured but probably around $75 \mu \mathrm{mol} \mathrm{m} \mathrm{m}^{-2} \mathrm{~s}^{-1}$ ), suggesting $\mathrm{C}$-stress (i.e. inadequate light) at this depth. The PFD at the base of the chl maximum was only $25 \mu \mathrm{mol} \mathrm{m} \mathrm{m}^{-2} \mathrm{~s}^{-1}$ (Fig. 3a); Garcia \& Purdie (1992) give a saturation of photosynthesis for Gyrodinium aureolum at ca $100 \mu \mathrm{mol} \mathrm{m} \mathrm{m}^{-2} \mathrm{~s}^{-1}$. The difference in the ratio of in vivo chl fluorescence to extracted chl a (Fig. 4) also suggests $C$-stress at depth; the ratio at $0 \mathrm{~m}$ increased from 0.08 during the day to over 0.25 at night, while at $10 \mathrm{~m}$ (where the PFD was less than $50 \mu \mathrm{mol} \mathrm{m} \mathrm{m}^{-2} \mathrm{~s}^{-1}$ during the day) the ratio was already high and declined at night. The implication of the rapid change in Gln/Glu (within $30 \mathrm{~min}$ ) is that the $\mathrm{C}-\mathrm{N}$ physiology of dinoflagellates fand quite likely of other phytoplankton) may change significantly and rapidiy in response to exposure to elevated PFD compared to that at the sampling depth. Such changes may be expected to affect adversely the usefulness of techniques exploring $\mathrm{C}-\mathrm{N}$ physiology which do not employ darkness during the incubation.

The chl maximum at Stn II contained 8.8 times the algal biomass (as biovolume) compared to that at Stn I, and the species composition was also different. The values of Gln/Glu for this advected population were low (around 0.1; Fig. 6b), and there was a lower concentration of amine $X$ relative to glutamate, suggesting a higher degree of N-stress (Flynn et al. 1993) in com- 

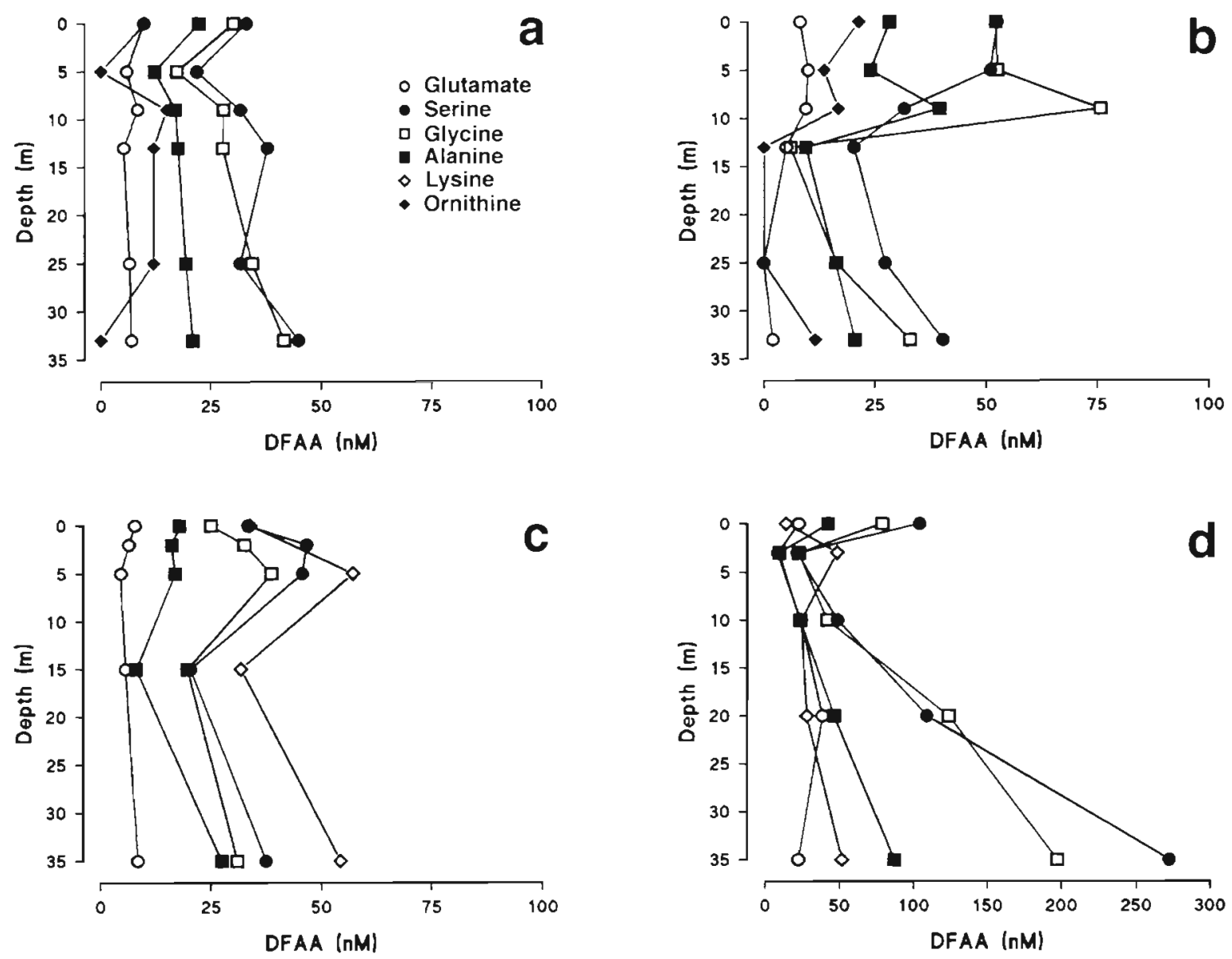

Fig. 10. Concentrations of the major components of dissolved free amino acids (DFAA) for the depth profiles at Stn I (a) in daylight and (b) at night; and at Stn II (c) in daylight and (d) at night. Ornithine is shown only for Stn I, and lysine only for Stn II; other values were not significant and are omitted for clarity

parison with that at Stn I. This view is consistent with lower concentrations of nitrate, around $0.1 \mu \mathrm{M}$ (increasing to $0.28 \mu \mathrm{M}$ at the bottom), and a slightly higher $\mathrm{C} / \mathrm{N}$ ratio. Also, the fluorescence response per unit of chl a was low (Fig. 4), consistent with $\mathrm{N}$-stress (Boyer et al. 1987); quenching is related in part to accumulation of diatoxanthin (Demers et al. 1991) which occurs in response to excess irradiance and/or to $\mathrm{N}$ stress. However, while $\mathrm{N}$-stressed algae normally show a marked stimulation of Gln/Glu on spiking with ammonium (Flynn et al. 1989, Flynn et al. 1993), the algae at Stn II showed little, or even a negative change in Gln/Glu in response to this treatment (Fig. 6b). This may be indicative of a difference in $\mathrm{N}$-assimilation pathways used by the algae at the 2 stations, because glutamate increased during spiking at Stn II with little or no change in glutamine; this was particularly noticeable towards the end of the sampling period (Fig. 6b). By the GS-GOGAT pathway, concentrations of gluta- mine should increase faster (or more in a 20 to $40 \mathrm{~min}$ incubation period) than glutamate, as observed at Stn I (Fig. 5a; see Flynn 1990a). The response shown at Stn II is more consistent with the use of the glutamate dehydrogenase (GDH) pathway, through which glutamate (rather than glutamine) is the initial product of ammonium assimilation (Syrett 1981). This could be a reflection of damaged chloroplastic systems given that GS is at least partly chloroplastic and GDH predominantly mitochondrial (see below). The lack of stimulation of Gln/Glu in the population at Stn II is similar to that we have observed with some laboratory cultures of old, stationary phase dinoflagellates which also displayed abnormal motility and shape (Flynn et al. 1993).

Despite the apparent difference in the $\mathrm{N}$-status of the 2 populations (as indicated by Gln/Glu, content of amine $\mathrm{X}$ relative to glutamate, fluorescence yield, slightly different $\mathrm{C} / \mathrm{N}$ and different concentrations of nitrate in the water) the dinoflagellates at Stn II still 
contained significant amounts of arginine and of other intracellular amino acids (Figs. $7 \& 8$ ). Further, in the majority of samples, concentrations of arginine increased in response to the incubation with ammonium (not shown). We have noted in our laboratory work that when growth of dinoflagellates ceases in the presence of nitrate, cells contain high (and sometimes extremely high) concentrations of free arginine within them (Flynn et al. 1993 and unpubl.). In this instance, the water contained little nitrate, but the cells at Stn II contained 4 times as much $\mathrm{N}$ as arginine- $\mathrm{N}$ than as glutamate-N (Fig. 8c and legend), while levels of arginine typically decline to near the limits of detection in N-starved algae (Flynn 1990b). Given the high numbers of predators also present at Stn II, however, it is possible that there was a significant level of ammonium regeneration, with a high flux and so a low residual concentration. Prego (1992) and Le Corre et al. (1993) suggest that concurrent ammonium regeneration may be an important $\mathrm{N}$-source for dinoflagellate blooms. If so, then the physiological status of the dinoflagellates, as demonstrable by the techniques described in this paper, may have profound effects on the development of the bloom and, where applicable, on the synthesis of paralytic shellfish toxins for which arginine is a precursor (Shimizu et al. 1990). (There was no hard evidence to suggest that the dinoflagellate population present at Stn II was toxic, although a local fish farmer reported unusual fish behaviour and some deaths during the event.)

From the above, we conclude that the physiology of the dinoflagellates at Stn II was fundamentally different to that at Stn I. While the general impression is that the population at Stn II was N-stressed, it responded to $\mathrm{N}$-refeeding in an abnormal fashion, and still retained high levels of $\mathrm{N}$-rich amino acids. Damage to the population at Stn II may have occurred during the advection event which resulted in their accumulation. The days preceeding sampling at Stn II had high surface PFDs, peaking at over $2000 \mu \mathrm{mol} \mathrm{m}^{-2} \mathrm{~s}^{-1}$ on 3 August. Garcia \& Purdie (1992) comment that in one of their cultures of Gyrodinium aureolum (one of the dominant dinoflagellates at Stn II), particularly severe photoinhibition was seen at PFD exceeding $600 \mu \mathrm{mol} \mathrm{m} \mathrm{m}^{-2} \mathrm{~s}^{-1}$ Photodamage, which may be expected to affect chloroplastic systems and associated biosynthetic apparatus more than others, would appear to have been a possibility.

Intracellular taurine appears to correlate with $\mathrm{chl}$ a for the populations at these stations (Fig 9). We have noted before that there is a correlation between taurine and cell number for Gymnodinium catenatum and Alexandrium tamarense (Flynn et al. 1993), and also for biovolume in the heterotrophic dinoflagellate Oxyrrhis marina (unpubl. data). The correlation appears to relate to the amount of cytoplasm; in old vacuolated cells or in prey-replete heterotrophs, taurine per cell is decreased. The fluctuation in taurine versus chl a was more pronounced for samples taken in the daylight. This may indicate populations of mixed physiological status. However, another problem with attempting to correlate taurine with chl $a$ is that it assumes that chl a correlates with biomass. Especially for dinoflagellates (Boyer et al. 1987, Reguera \& Oshima 1990, unpubl. data) the correlation between biomass and chl a may be very poor.

Concentrations of DFAA at Stn II were generally higher than those at Stn I (Fig. 10). However, there was no evidence of a significant accumulation of DFAA in the surface waters as has been reported for diatoms at the end of exponential growth (Hammer \& Eberlein 1981). The elevated levels of glycine and serine at depth are more likely the consequence of predator activity than of algal release, although ornithine (which may be associated with predator activity; Williams \& Poulet 1986) was only detectable at Stn I. The general composition of DFAA was similar at both stations, but both that and the concentration could also reflect processes of microbial uptake (Flynn \& Butler 1986). An important question leading from that is whether any release of DFAA by the dinoflagellates under different physiological conditions is associated with toxin synthesis by bacteria (Rausch de Traubenberg \& Lassus 1991). Trick et al. (1981) report release of a secondary metabolite from Prorocentrum minimum grown in culture, and we have detected an unidentified amine in the growth medium of Gymnodinium catenatum (Flynn et al. 1993). However, no unidentifed peaks were detected during the HPLC analysis of DFAA for this field study.

In conclusion, analysis of intracellular amino acids, especially with the additional step of a short-term incubation with added excess ammonium $(10 \mu \mathrm{M})$, appears to be a useful method to determine the physiological status of natural populations of dinoflagellates. Sensitivity of the method is high; only small sample volumes (the $50 \mathrm{ml}$ samples at $1 \mu \mathrm{g} \mathrm{l}^{-1} \mathrm{chl}$ a were more than sufficient) are required, containing a few hundred large dinoflagellate cells or more for smaller species (Flynn et al. 1993). Application of the method may be useful in determining the state of nuisance algae as they approach aquaculture facilities, and help to resolve the question of enhanced algal growth or metabolism on contact with nutrients released from such facilities. The method would also be of use in considering the question of nitrate uptake from a nutricline (Cullen \& Horrigan 1981, Holligan et al. 1984, Paasche et al. 1984) versus ammonium uptake from in situ ammonium regeneration during the growth of dinoflagellates (Dixon \& Holligan 1989, Prego 1992, Le Corre et al. 1993). 
Acknowledgements. This work was supported by funds, to K.J.F. and K.J.J., from the Natural Environment Research Council (UK). Phytoplankton identification was performed by Brendan Joyce (UC Galway). Instrument mooring design and construction was by Joe Graham and Neil McDougall, with hydrographic data analysis by Anton Edwards and Colin Griffiths (DML, Oban). K.J.F. wishes to thank John Patching (UC Galway) and the crew of the 'Lough Beltra' for making this work possible through access to ship time funded from the European Community (DGXII: Marine Science and Technology) in support of MAST programme 0017 'The Control of Phytoplankton Dominance

\section{LITERATURE CITED}

Anderson, D. M., Kulis, D. M., Sullivan, J. J., Lee, C. (1990). Dynamics and physiology of saxitoxin production by the dinoflagellates Alexandrium spp. Mar. Biol. 104: 511-524

Boyer, G. L., Sullivan, J. J., Andersen, R. J., Harrison, P. J., Taylor, F. J. R. (1987). Effects of nutrient limitation on toxin production and composition in the marine dinoflagellate Protogonyaulax tamarensis. Mar. Biol. 96: 123-128

Cullen, J. J, Horrigan, S. G. (1981). Effects of nitrate on the diurnal vertical migration, carbon to nitrogen ratio, and the photosynthetic capacity of the dinoflagellate Gymnodinium splendens. Mar. Biol. 62: 81-89

Delmas, D., Herbland, A., Maestrini, S. Y (1992). Environmental conditions which lead to increase in cell density of the dinoflagellate Dinophysis spp. in nutrient-rich and nutrient-poor waters of the French Atlantic coast. Mar. Ecol. Prog. Ser. 89: 53-62

Demers, S., Roy, S., Gagnon, R., Vignault, C. (1991). Rapid light-induced changes in cell fluorescence and in xanthophyll-cycle pigments of Alexandrium excavatum (Dinophyceae) and Thalassiosira pseudonana (Bacillariophyceae) - a photoprotection mechanism. Mar. Ecol. Prog. Ser. 76: 185-194

Dixon, G. K., Holligan, P. M. (1989). Studies on the growth and nitrogen assimilation of the bloom dinoflagellate Gyrodinium aureolum Hulburt. J. Plankton Res. 11 $105-118$

Flynn, K., Flynn, K. J., Jones, K. J. (1993). Changes in dinoflagellate intracellular amino acids in response to diurnal changes in light and N supply. Mar. Ecol. Prog. Ser. 100 $245-252$

Flynn, K. J. (1988). Some practical aspects of measurements of dissolved free amino acids in natural waters and within microalgae by the use of HPLC. Chem. Ecol. 3: 269-293

Flynn, K. J. (1990a). The determination of nitrogen status in microalgae. Mar. Ecol. Prog. Ser. 61: 297-307

Flynn, K. J. (1990b). Composition of intracellular and extracellular pools of amino acids, and amino acid utilization of microalgae of different sizes. J. exp. mar. Biol. Ecol. 139 $151-166$

Flynn, K. J. (1991). Algal carbon-nitrogen metabolism: a biochemical basis for modelling the interactions between nitrate and ammonium uptake. J. Plankton Res. 13: $373-387$

Flynn, K. J., Butler, I. (1986). Nitrogen sources for the growth of marine microalgae: role of dissolved free amino acids Mar. Ecol. Prog. Ser. 34: 281-304

Flynn, K. J., Dickson, D. M. J., Al-Amoudi, O. A. (1989). The ratio of glutamine:glutamate in microalgae: a biomarker for $\mathrm{N}$-status suitable for use at natural cell densities. J. Plankton Res. 11: 165-170

Flynn, K. J., Flynn, K. (1992). Nonprotein amino acids in microalgae; consequences for the estimation of the glutamine/glutamate ratio. Mar. Ecol. Prog. Ser. 89: 73-79

Fraga, F., Perez, F. F., Figueiras, F. G., Rios, A. F. (1992). Stochiometric variations of $\mathrm{N}, \mathrm{P}, \mathrm{C}$, and $\mathrm{O}_{2}$ during a Gymnodinium catenatum red tide and their interpretation. Mar. Ecol. Prog.Ser. 87: 123-134

Garcia, V. M. T., Purdie, D. A. (1992). The influence of irradiance on growth, photosynthesis and respiration of Gyrodinium cf. aureolum. J. Plankton Res. 14: 1251-1265

Hammer, K. D., Eberlein, K. (1981). Parallel experiments with Thalassiosira rotula in outdoor plastic tanks: development of dissolved free amino acids during an algal bloom. Mar. Chem. 10: 533-544

Holligan, P. M., Williams, P. J. LeB, Purdie, D., Harris, R. P. (1984). Photosynthesis, respiration and nitrogen suply of plankton populations in stratified, frontal and totally mixed shelf waters. Mar. Ecol. Prog. Ser. 17: 201-213

Jiménez, J., Niell, F. X., Figueiras, F. G., Clavero, V., Algarra P., Buela, J (1992). Green mass aggregations of Gyrodinium cf. aureolum Hulburt in the Ria of Pontevedra (north-west Spain). J. Plankton Res 14: 705-720

Jones, K. J., Gowen, R. J., Tett, P. (1984). Water column structure and summer phytoplankton distribution in the Sound of Jura, Scotland. J. exp. mar. Biol. Ecol. 78: 269-289

Le Corre, P., L'Helguen, S., Wafar, M. (1993). Nitrogen source for uptake by Gyrodinium cf. aureolum in a tidal front Limnol. Oceanogr. 38: 446-451

Le Févre, J. (1986). Aspects of the biology of frontal systems. Adv. mar. Biol. 23: 163-299

Martin-Jézéquel, V., Poulet, S. A., Harris, R. P., Moal, J., Samain, J. F. (1988). Interspecific and intraspecific composition and variation of free amino acids in marine phytoplankton. Mar. Ecol. Prog. Ser. 44: 303-313

Paasche, E., Bryceson, I., Tangen, K. (1984). Interspecific variation in dark nitrogen uptake in dinoflagellates. J. Phycol. 20: $394-401$

Prego, R. (1992). Flows and budgets of nutrient salts and organic carbon in relation to a red tide in the Ria de Vigo (NW Spain). Mar. Ecol. Prog. Ser. 79: 289-302

Raine, R., Joyce, B., Richard, J., Pazos, Y., Moloney, M., Jones, K. Patching, J. W. (1993a). The development of a bloom of the dinoflagellate Gyrodinium aureolum (Hulbert) on the south west Irish coast. ICES J. mar. Sci. 50: in press

Raine, R., Joyce, B., Patching, J. W., Jones, K., Richard, J. (1993b). Upwelling around the southwest Irish coast: nearsurface dynamics and blooms of the dinoflagellate Gyrodinium cf. aureolum (Hulbert). ICES CM 1993/L:17: 1-9

Rausch de Traubenberg, C., Lassus, P. (1991). Dinoflagellate toxicity: are marine bacteria involved? Evidence from the literature. Mar. microb. Fd Webs 5: 205-226

Reguera, B., Oshima, Y. (1990). Response of Gymnodinium catenatum to increasing levels of nitrate: growth patterns and toxicity. In: Granéli, E., Sundström, B., Edler, L., Anderson, D.M. (eds.) Toxic marine phytoplankton. Elsevier, New York, p. 316-319

Shimizu, Y., Gupta, S., Pradad, A. V. K. (1990). Biosynthesis of dinoflagellate toxins. In: Granéli, E., Sundström, B., Edler, L., Anderson, D.M. (eds.) Toxic marine phytoplankton. Elsevier, New York, p. 62-71

Strickland, J. D. H., Parsons, T R. (1972). A practical handbook of seawater analysis, 2nd edn. Bull. Fish. Res. Bd Can. 167

Syrett, P. J. (1981). Nitrogen metabolism in microalgae. Can. Bull. Fish. Aquat. Sci. 210: 182-210

Tett, P., Wallis, A. C. (1978). The general annual cycle of chlorophyll standing crop in Loch Creran. J. Ecol. 66: $227-239$ 
Trick, C. G., Harrison, P. J., Andersen, R. J. (1981). Extracellular secondary production by the marine dinoflagellate Prorocentrum minimum in culture. Can. J. Fish. Aquat. Sci. 38: 864-867

This article was submitted to the editor
Williams, R., Poulet, S. A. (1986). Relationship between the zooplankton, phytoplankton, particulate matter and dissolved free amino acids in the Celtic Sea. I. Unstratified water conditions. Mar. Biol. 90: 279-284

Manuscript first received: June 28, 1993

Revised version accepted: October 18, 1993 